\title{
WALTER SCOTT
}

Christopher Marlowe's Tragicall History of Dr Faustus - a very remarkable thing. Grand subject - end grand.

(from Scott's private notebook under the date 26 May 1797, in J. G. Lockhart, Memoirs of the Life of Sir Walter Scott, 7 vols (1837-8) I 264)

\section{HENRY MAITLAND}

Ir is obvious, that, as a whole, [Doctor Faustus] ... is exceedingly imperfect and disproportioned. The commencement and the conclusion are solemn, lofty - even magnificent - but the middle part is out of all keeping; and the ludicrous is therein not only too far prolonged, but too broadly drawn, and deeply coloured. The drama, too, comprehends a period of twenty-four years, and the actions and events are too few, and not sufficiently varied. Neither does Faustus seem to deserve the fearful punishment finally inflicted on him by Lucifer. At the same time, Marlow has shown great skill, and a deep knowledge of human nature, in not drawing Faustus as a monster of guilt and iniquity, so as to destroy all sympathy with his sufferings and fate. Though sold to Hell, he seeks rather his own enjoyment and pleasure than the misery of others, nor does he even seek them at the expense of his fellow creatures. When he delivers himself up to pleasure, his paramour is no innocent maiden whom his magic seduces, but the bright phantom of a former age, - and his licentiousness, even in its most criminal indulgencies, connects itself with the dreams of an imagination filled with all the forms of classical beauty. Goethe, on the other hand, in his powerful drama on the same subject, has driven Faustus over the edge, and down the abyss, of Sin. But we are not now going to criticise the work of the German philosopher. That we may do at another opportunity. Let us conclude with one remark - that while there is at 